\title{
Closed Shop Union Bylaws under the NLRA
}

Closed shop contracts, which prescribe union membership as a condition of initial and continued employment, ${ }^{1}$ were rendered illegal in $1947^{2}$ by the Taft-Hartley amendments to the NLRA, ${ }^{3}$ which sought to insure that refraining from union activities would not affect employment status. ${ }^{4}$ Nevertheless, some unions have attained closed shop conditions through devices such as closed shop bylaws, ${ }^{5}$ which prohibit union members from working with nonmembers. Employers expecting a substantial percentage of employees to comply with such bylaws often may seek to avoid labor problems by hir-

1 See generally G. BLOOM \& H. NORTHRUP, ECONOMICs of LABOR RELATIONS 220-3 (5th ed. 1965); H. MiLlis \& R. MONTGOMERY, 3 The Economics of LABOR-Organized Labor 470-85 (1945); R. LESTER, ECONOMICS OF LABOR 623 (1941).

2 Red Star Express Lines, Inc. v. NLRB, 196 F.2d 78 (2d Cir. 1952); C. GREGORY, LABOR AND LAW 393 (2d ed. 1958).

329 U.S.C. \$ 151 et seq. (1964).

429 U.S.C. $\S 157$ (1964), $\$ 7$ of the National Labor Relations Act, as amended, reads: Employees shall have the right to self-organization, to form, join, or assist labor organizations, to bargain collectively through representatives of their own choosing, and to engage in other concerted activities for the purpose of collective bargaining or other mutual aid or protection, and shall also have the right to refrain from any or all of such activities except to the extent that such right may be affected by an agreement requiring membership in a labor organization as a condition of employment as authorized in section 158(a)(3) of this title.

The right to refrain from union activities was added in 1947. 29 U.S.C. § 158(a)(3) (1964), \$ $8(a)(3)$ of the Act, reads:

(a) It shall be an unfair labor practice for an employer-

(3) by discrimination in regard to hire or tenure of employment or any term or condition of employment to encourage or discourage membership in any labor organization: ... Provided further, That no employer shall justify any discrimination against an employee for nonmembership in a labor organization (A) if he has reasonable grounds for believing that such membership was not available to the employee on the same terms and conditions generally applicable to other members, or (B) if he has reasonable grounds for believing that membership was denied or terminated for reasons other than the failure of the employee to tender the periodic dues and the initiation fees uniformly required as a condition of acquiring or retaining membership.

Clause (B) of the last proviso has been interpreted to mean that security agreements cannot require full union membership as $\$ 7$ implies, but only payment of dues and initiation fees. Radio Officers' Union v. NLRB, 347 U.S. 17, 40 (1954).

5 The earlier union efforts to obtain closed shop conditions were through the use of bylaws rather than contracts. In 1817 the Carpenters' Company of Philadelphia adopted the following provision:

If any member of this Company, shall measure, and value Carpenter work with

any person not a member, on proof thereof at their meeting, [he], shall be expelled from the Company.

I J. Commons, History of Labour in the United States 81 (1936). L. Ulman, The Rise 
ing only union men. The bylaws thus fulfill the same function as illegal closed shop contracts. ${ }^{6}$ In spite of their illegal purpose, courts have held that the NLRA does not proscribe the maintenance or enforcement of these bylaws. ${ }^{7}$

The recent Supreme Court decision in Scofield $v . N L R B, 8$ enunciating standards for determining the enforceability of union bylaws, and the developing union duty of fair representation, adopted by the Board in Miranda Fuel Co., ${ }^{9}$ invite a reconsideration of the status of closed shop bylaws under the NLRA. ${ }^{10}$

This comment will consider the legality of ( 1 ) union efforts, through internal disciplinary action, to encourage membership compliance with these bylaws; and (2) union efforts, through actual or threatened economic action, to encourage employer compliance. Fi-

of the National TRADE Union 73 (1966) lists the obligations not to work with nonmembers and not to work below union rates as the two primary responsibilities early trade unions sought to impose on their members.

Closed shop bylaws appear to be commonly used in industries, such as construction and entertainment, involving temporary jobs with a high frequency of employee and employer turnover. In these industries, union bylaws prescribing the conditions under which members will accept employment often become the equivalent of a collective contract. See American Fed'n of Musicians v. Carroll, 391 U.S. 99, 104 (1968); Summers, Legal Limitations on Union Discipline, 64 HARv. L. REv. 1049, 1064 (1951). Maintenance of closed shop conditions seems especially important in these industries since union control might be difficult to maintain if unaffiliated workers had the unrestricted opportunity to enter the industry at the outset of each job.

B Functionally, closed shop bylaws seem to differ from closed shop contracts only in the manner in which they are enforced. If a contract were enforceable, closed shop conditions would be maintained for the term of the contract by ordinary breach of contract remedies or by economic sanctions available to the unions. Only economic sanctions are available to force employers to comply with the policy of closed shop bylaws. However, the duration of closed shop conditions maintained by restrictive bylaws may often equal or exceed the average contract term since the closed shop itself tends to promote union strength by discouraging the tendency of union men to let membership lapse, by preventing employers from gradually replacing union members with nonunionists, and by increasing the difficulty of a successful membership raid by a rival union. H. Milles \& R. MONTGOMERY, supra note 1 , at 479; B. LESTER, supra note 1 , at 622 ; G. BLoom \& H. NORTHRUP, supra note 1 , at 222.

7 Glasser v. NLRB, 395 F.2d 401 (2d Cir. 1968); American Newspaper Publishers Ass'n v. NLRB, 193 F.2d 782 (7th Cir. 1951).

8394 U.S. 423 (1969).

o 140 N.L.R.B. I8I (1962).

10 Their legality might also be questioned under Title VII of the Civil Rights Act of 1964. 42 U.S.G. $\S 2000 \mathrm{e}$ to $\S 2000 \mathrm{e}-15$ (1964). In the construction trades, where unions are often overwhelmingly white, closed shop conditions attributable to restrictive bylaws serve to exclude blacks. Thus closed shop bylaws can be instruments of discrimination subject to attack in the same manner as discriminatory admission standards. This comment will not consider the implications of Title VII. For a discussion of these issues see Comment, Title VII of the Civil Rights Act of 1964 and Minority Group Entry into the Building Trade Unions, 37 U. CHI. L. REv. 328 (1970). 
nally, this comment will consider whether maintenance of a closed shop bylaw should constitute a per se violation of the Act.

\section{Union Efforts to Encourage Membership Compliance}

Apart from informal pressure from fellow members and union officials, membership compliance is commonly obtained through enforcement of the bylaw by internal union disciplinary proceedings. Both the NLRB and the courts have held that the internal enforcement of closed shop bylaws does not violate section $8(\mathrm{~b})(1)(\mathrm{A})^{11}$ because the bylaws are protected by the proviso to that section, ${ }^{12}$ which states that "this paragraph shall not impair the right of a labor organization to prescribe its own rules with respect to acquisition and retention of membership."13 These holdings are called into question by the Supreme Court opinion in Scofield $v$. $N L R B,{ }^{14}$ which delineated standards for determining the enforceability of union rulesstandards that the Court was groping toward in the two preceding cases on union discipline, ${ }^{15}$ NLRB $v$. Allis-Chalmers $M f g$. Co. ${ }^{16}$ and NLRB v. Marine Workers Union.17

In Allis-Chalmers, the Court faced the question of whether a union "restrained or coerced" section 7 rights in violation of $8(b)(1)(A)$ by suing in state court to collect reasonable fines imposed on members

1129 U.S.C. \& 158(b)(1)(A) (1964) reads:

(b) It shall be an unfair labor practice for a labor organization or its agents-

(1) to restrain or coerce (A) employees in the exercise of the rights guaranteed in section 157: . . . Provided, That this paragraph shall not impair the right of a labor organization to prescribe its own rules with respect to the acquisition or retention of membership therein.

12 In International Typographical Union, 86 N.L.R.B. 951, 957 (1949), the Board refused to find an $8(b)(1)(A)$ violation in the union's attempt to enforce closed shop bylaws with threats of expulsion, even though expulsion could have resulted in loss of employment or pension benefits. The Seventh Circuit approved the Board's conclusion with the statement that "[m]embers could be expelled for any reason and in any manner prescribed by the organization's rules, so far as $\S 8(\mathrm{~b})(\mathrm{I})(\mathrm{A})$ is concerned." American Newspaper Publishers Ass'n v. NLRB, 193 F.2d 782, 800 (7th Cir. 1951). More recently, Glasser v. NLRB, 395 F.2d 401 (2d Cir. 1968), approved the same result.

1329 U.S.C. \& $158(\mathrm{~b})(1)(\mathrm{A})$ (1964).

14394 U.S. 423 (1969), aff'g 393 F.2d 49 (7th Cir. 1968). The Seventh Circuit held that no $8(\mathrm{~b})(1)(A)$ violation had occurred since the union fines conformed "to policies formulated by the union and not violative of its constitution or of federal law." Id. at 53. See 33 NLRB ANN. REP. 156 (1968) which did not recognize the Seventh Gircuit's decision as limiting the scope of the proviso. Cf. American Newspaper Publishers Ass'n v. NLRB, 193 F.2d 782, 800 (7th Cir. 1951) (note 12 supra).

15 Silard, Labor Board Regulation of Union Discipline after Allis-Chalmers, Marine Workers, and Scofield, 38 GEO. WASH. L. REv. 187 (1969).

16388 U.S. 175 (1967).

17391 U.S. 418 (1968). 
for violating a bylaw against strikebreaking. The Court first recognized that a union was free under the proviso to expel members for nonpayment of fines. ${ }^{18}$ It then reasoned that court collection of fines, which it viewed as a lesser penalty than expulsion, should likewise be upheld. Thus, though the Court avoided ruling on whether court collection fell within the proviso, ${ }^{19}$ the proviso was decisive in the Court's conclusion that court enforcement of fines for strikebreaking did not constitute $8(\mathrm{~b})(\mathrm{I})(\mathrm{A})$ restraint or coercion. In reaching this conclusion, the majority also emphasized the essential union interest served by enforcement of a bylaw against strikebreaking. ${ }^{20}$

The Allis-Chalmers opinion seems to use the $8(\mathrm{~b})(\mathrm{l})(\mathrm{A})$ proviso, and the Court's judgment of what the value of union membership should be, to define "restrain or coerce."21 If expulsion would be a proper penalty for a member's misconduct, a lesser penalty would be upheld. But the Court's opinion is of little assistance in determining when expulsion would be a proper penalty and which specific penalties would be viewed as lesser penalties than expulsion. ${ }^{22}$ The Court clearly did not approve court collection of fines for violation of all union bylaws, ${ }^{23}$ although it did not expressly repudiate earlier, decisions allowing expulsion for any reason prescribed by a union's rules. ${ }^{24}$

The question of when expulsion would be improper was given initial consideration in NLRB v. Marine Workers Union. ${ }^{25}$ A union member filed a complaint with the Board that the union had caused his employer to discriminate against him for engaging in protected activity. The union expelled the member for filing the complaint in violation of a bylaw requiring exhaustion of internal union remedies. Emphasizing the importance of free access to the Board's unfair labor practice machinery, the Court approved Board holdings ${ }^{26}$ that enforcement of union rules which deterred members from filing complaints was not protected by the proviso to $8(\mathrm{~b})(\mathrm{l})(\mathrm{A})$. In the Court's view, unions had no legitimate interest in impeding access

18388 U.S. at 191-3.

$10 \mathrm{Id}$. at $192 \mathrm{n} .29$.

$20 \mathrm{Id}$. at 195.

21 See Note, Fair Representation and Union Discipline, 79 YALE L.J. 730, 737 (1970).

22 See generally Christensen, Union Discipline Under Federal Law: Institutional Dilemmas in an Industrial Democracy, 43 N.Y.U.L. REv. 227, 264 (1968).

23388 U.S. at 181 (emphasizing importance of strikes to unions); id. at 198-9 (concurring opinion of Justice White).

24 See note 12 supra.

25391 U.S. 418 (1968).

26 Charles S. Skura, 148 N.L.R.B. 679 (1964); H. B. Roberts, 148 N.L.R.B. 674 (1964), enforced, 350 F.2d 427 (D.C. Cir. 1965); Marine Workers Union, I59 N.L.R.B. 1065 (1966). 
to the Board except when "plainly internal affairs of the union are involved." 27 The Court then characterized the "causing to discriminate" charge as a "matter that is within the public domain and beyond the internal affairs of the union." 28 Thus, the Court held that $8(\mathrm{~b})(\mathrm{I})(\mathrm{A})$ insulated a member who filed such a charge from even wholly internal union expulsion proceedings-as compared with the court actions approved in Allis-Chalmers-to enforce a bylaw requiring exhaustion of internal union remedies. ${ }^{29}$

Scofield elaborated on Marine Workers by setting out a more general test for determining when rules are unenforceable:

... it has become clear that if the rule invades or frustrates an overriding policy of the labor laws, the rule may not be enforced, even by fine or expulsion, without violating $\S 8(\mathrm{~b})(\mathrm{I}) .^{30}$

The opinion also clarified the nature of union rules which were protected by the proviso and enforceable:

$\ldots 8(b)(1)$ leaves a union free to enforce a properly adopted rule which reflects a legitimate union interest, impairs no policy Congress has imbedded in the labor laws, and is reasonably enforced against union members who are free to leave the union and escape the rule. ${ }^{31}$

Under this standard, Scofield concluded that a rule against exceeding production ceilings was enforceable since the narrow limitation of section $8(\mathrm{~b})(6)^{32}$ does not represent a national policy against featherbedding. ${ }^{33}$ After determining that the production ceiling was enforceable, the Court, without further discussion, held that court actions to enforce the rule were permissible. ${ }^{34}$ This silent acquiescence in the Allis-Chalmers result might be interpreted as implying that union rules are either enforceable to the extent of penalties equivalent in severity to expulsion, or wholly unenforceable. ${ }^{35}$

The Board, however, has found it necessary to refine the Scofield analysis by rejecting this implication. In International Molders Local 125,36 the Board held that unions violated $8(\mathrm{~b})(\mathrm{l})(\mathrm{A})$ by levying

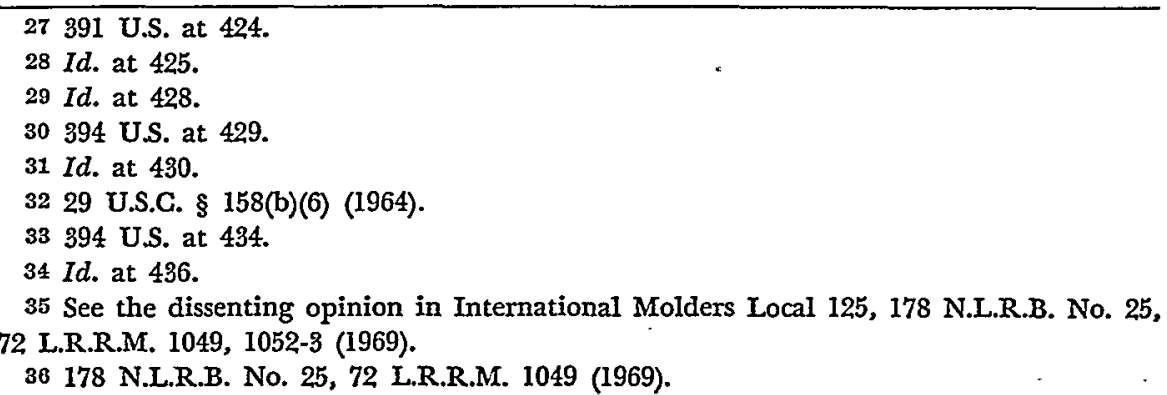


fines on members for filing decertification petitions with the Board even though in similar situations it had upheld expulsions. ${ }^{37}$ The fine was characterized as a "punitive measure-to discourage members from seeking . . . access to the Board's processes," 38 whereas expulsion was permissible as a measure of union "self-defense"-to prevent the member seeking decertification from being "privy to the union's [pre-election] strategy and tactics." 30 Thus, under the Board's most recent approach, union rules cannot be neatly categorized as enforceable or unenforceable. Rather, the legality of enforcement mechanisms may depend on the union's purpose in enforcing the rule and the effect of enforcement.

Closed shop bylaws seem to fall clearly within the category of unenforceable bylaws as defined by Scofield. The Supreme Court has often stated that the "policy of the Act is to insulate employees' jobs from their organizational rights." 40 The purpose of enforcing closed shop bylaws, whether by fine or expulsion, is to coerce membership compliance with the bylaw and thus affect the employment status of nonmembers (including members expelled through enforcement proceedings) in clear violation of that policy. Indeed, the only union interest served by enforcement of the bylaw seems to be maintenance of closed shop conditions. Without any legitimate justification, enforcement infringes on the express section 7 right of employees (including members) to refrain from organizational activities. ${ }^{41}$ Closed shop bylaws thus impair a "policy Congress has imbedded in the labor laws"42 and would seem to be wholly unenforceable under $8(\mathrm{~b})(\mathrm{l})(\mathrm{A}) .^{43}$

\section{Union Efforts to Encourage EMployer Compliance}

Conduct ranging from bitter strikes to friendly telephone conversations may be utilized to obtain employer compliance with the bylaws under discussion. An employer violates 8(a)(3) when he adopts a closed shop policy, and a union which causes or attempts to cause an employer to adopt such a policy violates $8(\mathrm{~b})(2)$. Further, since

37 Tawas Tube Prods., Inc., 151 N.L.R.B. 46 (1965); Price v. NLRB, 373 F.2d 443 (9th Cir. 1967).

38178 N.L.R.B. No. 25, 72 L.R.R.M. at 1050.

39 Id. (quoting Price v. NLRB, supra note 37 ).

40 Radio Officers' Union v. NLRB, 347 U.S. 17, 40 (1954).

41 Except to the extent that financial support may be demanded under valid union security provisions. See note 4 supra.

42 Scofield v. NLRB, 394 U.S. 423, 430 (1969).

$43 \mathrm{Id}$. at 436. The Court disapproved enforcement of rules which "induced . . . dis crimination by the employer against any class of employees. . . Id. 
a union purpose to cause that effect can often be inferred from the nature of the conduct utilized to obtain employer compliance, ${ }^{44}$ it is possible to find an $8(\mathrm{~b})(2)$ violation without proof that the union conduct was actually pursuant to a closed shop bylaw. For instance, a strike actively sponsored by the union for the purpose of attaining a closed shop violates $8(\mathrm{~b})(2)$ even if no bylaw exists. ${ }^{45}$ The bylaw may, however, be relevant to finding an $8(\mathrm{~b})(2)$ violation in at least three identifiable situations: when the union advises an employer of its intention to enforce its bylaw against his employees; ${ }^{46}$ when there is internal enforcement of the bylaw against the employees of a particular employer; and when there is membership compliance with the bylaw.

\section{A. Statements to the Employer}

Prior to Scofield, the Second Circuit, in Glasser v. NLRB, ${ }^{47}$ announced a test for determining when union conduct pursuant to a closed shop bylaw violates $8(\mathrm{~b})(2)$ 's prohibition against causing or attempting to cause employer discrimination: ${ }^{48}$

$\ldots$ in order for union conduct to violate section $8(b)(2)$, as opposed to section $8(\mathrm{~b})(1)(\mathrm{A})$, there must be some direct approach to the employer, or some conduct aimed at him, for the purpose of causing the employer to discriminate by implementing the union bylaw through his hiring practices or otherwise. ${ }^{49}$

44 See Radio Officers' Union v. NLRB, 347 U.S. 17, 50 (1954); NLRB v. Local 50, Bakery \& Confectionery Workers, 339 F.2d 324 (2d Cir. 1964). Cf. NLRB v. St. Joe Paper Co., 319 F.2d 819 (2d Cir. 1963) (casual conversation with employer in which union president made derogatory remarks about employee, plus substantial evidence of intent to cause employee's dismissal, constituted a violation). See generally Christensen \& Svanoe, Motive and Intent in the Commission of Unfair Labor Practices: The Supreme Court and the Fictive Formality, 77 YALE L.J. 1269 (1968); Note, Employer Motivation Under Section $8\left(a X^{3}\right)$ of the National Labor Relations Act, 43 NOTRE DAME LAW. 202 (1967).

45 Flack v. NLRB, 327 F.2d 396 (7th Cir. 1963). (When illegal purpose of strike is ascertainable, a clear demand to the employer that he discriminate is not necessary.)

46 Since $\$ 8(\mathrm{~b})$ of the NLRA applies only to "a labor organization or its agents," it is necessary to determine whether notice specifically communicated to an employer is attributable to the union. Court decisions indicate that a union is responsible for notice given by a union steward, business agent, president or other union member with apparent authority to inform employers of union action. See, e.g., NLRB v. Teamsters Local 815, 290 F.2d 99 (2d Cir. 1961); Sunset Line and Twine Co., 79 N.L.R.B. 1487 (1948). On the other hand, a union is not responsible for notice of union action specifically given to an employer by an individual whom the bylaw does not authorize to give such notice. See, e.g., Superior Engraving Co. v. NLRB, 183 F.2d 783 (7th Cir. 1950); Perry Norvell Co., 80 N.L.R.B. 225 (1948).

47395 F.2d 401 (2d Cir. 1968), denying review to American Fed'n of Musicians, 16E N.L.R.B. 798 (1967).

4829 U.S.C. § I58(b)(2) (1964).

$49395 \mathrm{~F} .2 \mathrm{~d}$ at 406 (emphasis added). 
Under this standard, the court held that the maintenance and internal enforcement of a closed shop bylaw, applicable only to employee members of the American Federation of Musicians, did not violate the Act. ${ }^{50}$

The Second Circuit did not set forth the reasoning behind its requirement of a "direct approach," but it did cite two cases as authority for this requirement: NLRB $v$. Plumbers \& Pipefitters Local $2^{51}$ and United Nuclear Corp. v. NLRB.52 Neither of these cases, however, necessarily supports the requirement of a "direct approach." Although Plumbers and Nuclear undeniably stand for the proposition that a "direct approach" constitutes a violation, ${ }^{53}$ they do not suggest, as Glasser held, that a direct approach is necessary to find such a violation.

Thus, Glasser did not sufficiently explain how or why it developed its specification of the degree of proximate causation necessary for a violation of $8(\mathrm{~b})(2)$. But the court's direct approach test does seem to result in a rather vague reformulation of the traditional distinction ${ }^{5 *}$ between enforcement of union rules with permissible "internal" sanctions having little impact outside the organization ${ }^{55}$ and

50 The only remaining issue in Glasser was whether processing charges against orchestra leaders subject to Board jurisdiction was a violation of the Act. The court concluded that processing charges was nothing more than a series of ministerial steps to which no significance would be attached. Id. at 404 .

51360 F.2d 428 (2d Cir. 1966). The Plumbers case involved a strike which erupted when the New York City Commission on Human Rights persuaded an employer in the construction industry to hire four nonunion minority group workers. The local, by endorsing the walkout as an expression of each individual member's choice not to work with nonunion men and by refusing to refer substitute workers to the site, was held by the court to have violated $8(\mathrm{~b})(1)(\mathrm{A})$ and $8(\mathrm{~b})(2)$.

52340 F.2d 133 (1st Cir. 1965). In the Nuclear case the union had demanded that fifty employees be dismissed, alleging that they had failed to comply with a provision of the collective bargaining contract requiring maintenance of membership by employees who were union members at the time the agreement was made or who thereafter voluntarily became union members. The corporation refused to dismiss the men, and the union filed a grievance. Judge Wyzanski held that filing a grievance constituted a violation of $8(\mathrm{~b})(\mathrm{I})(\mathrm{A})$ and $8(\mathrm{~b})(2)$ because the employees in question had, in fact, never been union members.

53 The Glasser opinion evidently interpreted the union conduct in Plumbers (endorsement of a walkout and refusal to refer substitute workers to the struck site), and the union conduct in Nuclear (filing a grievance alleging that employees who had never been union members violated the maintenance of membership contract) to be "direct approaches to the employer, ... . for the purpose of causing the employer to discriminate." 395 F.2d at 406 (2d Cir. 1968).

54 See Scofield v. NLRB, 394 U.S. 423 (1969); Union Starch \& Ref. Co. v. NLRB, 186 F.2d 1008 (7th Cir. 1951); Minneapolis Star and Tribune, 109 N.L.R.B. 727 (1954); Christensen, supra note 22, at 272.

65 See, e.g., Ohio Valley Carpenters' Dist. Council, AFL-CIO, 131 N.L.R.B. 1130 (1961), where the Board refused to find a violation when employee members complied with 
enforcement of union rules with prohibited "external" sanctions affecting employment status. ${ }^{50}$

The Board subsequently applied the Glasser direct approach test as though it were a rigid rule, rather than a vague restatement of precedents, and reached a result contrary to the basic purposes of the statute. In Musicians Local 802,57 Joseph Carroll, ${ }^{58}$ an orchestra leader, engaged members of a musicians local for two performances through his hiring agent and conductor, one Cardelli, a union member. Prior to the first engagement, three of the musicians were expelled from the union for violations of the closed shop bylaw upheld in Glasser. On the morning of the first performance, a fourth orchestra member informed Cardelli that he would not perform with the expelled musicians. At Carroll's request, Cardelli telephoned the union president and was informed:

You are familiar with the bylaw. The bylaw speaks for itself. It is perfectly all right for those three nonmembers to play, but if they play and you play with them, the union members, the other members of the union and you will be brought up on charges. ${ }^{59}$

Cardelli then informed Carroll that he would not perform with the nonmembers, whereupon Carroll instructed him to replace them with union members.

The dismissals were clearly contrary to the national labor legislation policy to "insulate employees' jobs from their organizational rights," 60

closed shop bylaws rather than risk a fine or expulsion resulting in the loss of employment because of the existence of closed shop conditions.

56 See, e.g., Miami Valley Carpenters' Dist. Council, AFL-CIO, 129 N.L.R.B. 517 (1960) (instructions from a union agent to a job foreman and union steward that a member who had refused to pay a fine and whose tender of dues was consequently refused was not to work until his fine and dues were paid); Bricklayers Local 11, 144 N.L.R.B. 373 (1963) (a letter to an employer stating that a man who had been dropped from membership ".. does not belong on the job. If your company continues to employ this man, our union is not responsible for the actions of its members ..." coupled with the business agent informing the steward of the letter). Id. at 374; Operating Eng'rs Local 17, 143 N.L.R.B. 29 (1963) (a master mechanic, who was president of his local, rejecting the job application of a nonunion oiler, ostensibly for safety reasons, and at the same time filing charges for violation of closed shop rules against the member machine owner who had recommended the oiler for the job); Operating Eng'rs Local 9, 147 N.I.R.B. 393 (1964) (union failure to provide a nonunion employee with fifteen years experience with a referral slip coupled with the union members' refusal to work with the man).

57176 N.L.R.B. No. 76, 71 L.R.R.M. 1228 (1968).

58 This was not Carroll's first dispute with the Musicians Union. See American Fed'n of Musicians v. Carroll, 391 U.S. 99 (1968).

69176 N.L.R.B. No. 76; 71 L.R.R.M. at 1228 (1968).

60 Radio Officers' Union v. NLRB, 347 U.S. 17, 40 (1954). 
and a violation of the Act would seem to have been established on the basis of previous decisions involving discrimination induced by efforts to implement closed shop bylaws. ${ }^{01}$

The Board concluded, however, that due to the protection of the proviso the dismissals did not violate $8(\mathrm{~b})(\mathrm{I})(\mathrm{A})$, and because a "direct approach" had not been established, the dismissals did not violate 8(b)(2). Accepting the Glasser holding that maintenance and internal enforcement of closed shop bylaws did not violate the Act, ${ }^{62}$ the Board viewed the decisive question in the case to be "whether [union] officials caused or attempted to cause the Employer to discriminate against his nonunion employees when, in response to the Employer's direct and insistent questioning, they stated that the Union would in fact do what it had an undisputed right to do-enforce its bylaw."63 Noting that the union had not initiated the phone conversation "to bring the bylaw to [the employer's] attention," the Board emphasized that in response to the employer's inquiries, the union "did no more than repeat what Carroll already knew, namely, that the bylaw existed, and confirm what he must have suspected, namely, that no exception would be made in favor of members who played with [the nonmembers]." 64

Since the discharges were clearly discriminatory, one might have expected the Board to hold that Carroll had violated sections 8(a)(3) and $8(a)(1)$. But the Board apparently felt that to find a violation by an employer whose actions were compelled by the operation of a closed shop bylaw would have been unfair. ${ }^{65}$ It held that the restrictive bylaw, known to both the employer and the employees, all of whom were union members at the time the employment contracts were made, created an "implied condition that nothing would occur prior to the time of the performance which would alter the all-union character of the orchestra." 66 Carroll was excused from performance of the employment contracts for failure of this implied contractual condition. Thus, the Board ruled that Carroll had not violated the Act.

61 Union: see, e.g., Plumbers \& Pipefitters Local 2, 152 N.L.R.B. 1093 (1965); Operating Eng'rs Local 17, 143 N.L.R.B. 29 (1963); Miami Valley Carpenters' Dist. Council, AFLCIO, 129 N.L.R.B. 517 (1960). Both union and employer: Westwood Plumbers, 122 N.L.R.B. 726 (1958). Cf. Ohio Valley Carpenters' Dist. Council, AFL-CIO, 131 N.L.R.B. 1130 (1961) (no violation where prospective employees who were members of other locals voluntarily sought to comply with the bylaw by obtaining work permits).

62 See Glasser v. NLRB, 395 F.2d 401 (2d Cir. 1968).

63176 N.L.R.B. No. 76, 71 L.R.R.M. 1228, 1230 (1968).

64 Id.

65 "Thus, the Employer's predicament resulted, independently of any improper motive or unlawful union pressure, from the operation of a bylaw provision which both the Board and the courts have found to be protected by the proviso of Section $8(b)(1)(B) . "$ Id. at 1231 .

60 Id. 
The Board's wooden application of the "direct approach" test to excuse the union emphasized factors which should not have been controlling: that the employer had initiated the phone conversation and that the union's response conveyed no new information. Even under pre-Scofield law, these facts should not excuse a coercive union threat ${ }^{67}$ inducing employer discrimination. Moreover, the Board's invocation of contract doctrine to excuse the employer because of failure of an implied condition contrary to the purposes of the Act directly conflicts with holdings that an employer is not bound by union rules absent an agreement to that effect. ${ }^{68}$ To write the restrictive bylaw into an implied contract, and to validate employer action in conformity with that contract, disregards fundamental contract doctrine and the supremacy of the NLRA over agreements repugnant thereto. ${ }^{69}$

The central difficulty in the decision, however, was the Board's acceptance of pre-Scofield holdings that maintenance and internal enforcement of closed shop bylaws do not violate the Act. A statement to an employer that a union intends to enforce a closed shop bylaw would seem to have some coercive impact in that it indicates the union's desire for closed shop conditions. ${ }^{70}$ Since the bylaw itself can serve as evidence of the union's purpose, such a statement of intended enforcement would seem to constitute a technical violation even under the Glasser direct approach test. The Board chose to ignore that technical violation, however, and held that under the circumstances of the case, the union's pre-Scofield right to enforce the bylaw gave the union the right to state that the bylaw would be enforced. But since Scofield implies that a union no longer has a right to enforce a closed shop bylaw, a union's statement to an employer of its intent to enforce such a bylaw should no longer be given ancillary protection and should be held to violate section $8(b)(2)$ as a substantial component of a plan to cause employer discrimination.

\section{B. Internal Enforcement}

Rather than focusing solely on the telephone conversation, the Board should also have considered whether internal enforcement of the Musicians Local bylaw constituted an $8(b)(2)$ violation. Since

67 That the statement threatens action which might be protected by $8(\mathrm{~b})(1)(\mathrm{A})$ seems irrelevant. See note 70 infra.

68 Ohio Valley Carpenters' Dist. Council, AFL-CIO, 131 N.L.R.B. 1130. (1961); Bowling Supply and Serv., Inc., 127 N.L.R.B. 1073 (1960).

69 E.g., Red Star Express Lines, Inc. v. NLRB, 196 F.2d 78 (2d Cir. 1952).

70 The fact that it is a statement of an intention to perform a legal act (before Scofield) would ordinarily not be grounds to ignore its coercive impact. See Building \& Constr. Trades Council, 162 N.L.R.B. 605, 609 (1967). 
Scofield denies the union the right of internal enforcement under $8(\mathrm{~b})(1)(\mathrm{A})$, and since the proviso to that section does not apply to $8(\mathrm{~b})(2)$, the Board should not have ignored the coercive impact internal enforcement has on an employer. To violate $8(b)(2)$, internal enforcement must "cause" or "attempt to cause" an employer to discriminate. Internal enforcement indicates: first, that the union is actively pursuing a closed shop policy; and second, since the union can expect penalized members and their brethren to pressure their employer to discharge nonmembers (including expelled members), that the union's policy is effectively imposed on the employer. As Musicians Local demonstrates, the immediate effect of internal enforcement is to influence members to refuse to work until closed shop conditions are achieved. Since an actor generally is held to intend the foreseeable consequences of his acts, ${ }^{71}$ internal enforcement of the bylaw should constitute union intent to cause prohibited employer discrimination.

When employer discrimination has been in response to both notice from the union that the bylaw is being enforced and refusal of members to work with nonmembers, the tendency of the Board has been, as in Musicians Local, to focus on the notice as the "cause" of the discrimination. But when a union enforces its bylaw, it should certainly expect the employer to learn of its desires, if not through notice from a union official, then through the economic pressure exerted when member employees, in response to internal enforcement, refuse to work with nonmember employees. Thus, in cases like Musicians Local, both the means of notification and the internal disciplinary proceedings to enforce the bylaw "cause" employer discrimination. To concentrate analysis on the former and ignore the latter seems misguided, especially since the statute also reaches "attempt[s] to cause" discrimination. Even when union efforts to implement a closed shop are unsuccessful, internal enforcement may be viewed as a substantial component of a plan to accomplish prohibited discrimination. Thus, disciplinary proceedings to enforce a closed shop bylaw seem to constitute an "attempt to cause" discrimination even in the absence of a discriminatory employer response.

\section{Membership Compliance}

Membership compliance with closed shop bylaws by refusing to work with nonmembers violates $8(b)(2)$ if union responsibility for the members' acts can be established, ${ }^{72}$ and if the requisite causal relation-

71 Radio Officers' Union v. NLRB, 347 U.S. 17, 45 (1954).

72 Under § 8(b) of the NLRA it is only conduct by "a labor organization or its agents" 
ship and union purpose are present. When members take concerted economic action against an employer, the threshold issue of union responsibility is disposed of by a strong presumption holding the union answerable for the members' conduct. ${ }^{73}$ This presumption is not dependent on whether the concerted acts are in compliance with a bylaw. Only by taking affirmative action to disavow the members' conduct can the union avoid being answerable for concerted economic action. ${ }^{74}$ When conduct of members cannot be characterized as concerted, no presumption of union responsibility arises. However, when individual action is in compliance with a closed shop bylaw, maintenance of the bylaw may be sufficient evidence of union authorization to hold the union responsible under the Act.

Members may comply with closed shop bylaws either by walking off a job in protest of the presence of nonunion employees or by refusing to apply for work with an employer who employs nonunion men. A walkout for the disclosed purpose of implementing a closed shop bylaw exerts coercive pressures on an employer to take discriminatory action, ${ }^{75}$ and in such a case a prohibited purpose can be conclusively presumed. Since a strike for legitimate ends by a union maintaining a closed shop bylaw should not be an unfair labor practice, proving that a challenged walkout actually was prompted by the bylaw appears to be the only prerequisite for finding an $8(\mathrm{~b})(2)$ violation. ${ }^{76}$

that is proscribed. For determination of when one is an agent see Evans, The Law of Agency and the National Union, $49 \mathrm{KY}$. L.J. 295, 313 (1961). A member of a labor organization is not ipso facto an agent of the organization, even when his conduct may implement or be intended to implement the policies of the union. NLRB v. Cement Masons Local 555, 225 F.2d 168, 173 (9th Cir. 1955); Meat Cutters Local 303, 93 N.L.R.B. 336 (1951). However, a union may be responsible for members' conduct even though the members are not individually answerable under $8(\mathrm{~b})$ as agents. Perry Norvell Co., 80 N.L.R.B. 225 (1948); Local 760, IBEW, 82 N.L.R.B. 696 (1949) (mass quitting raises presumption of union responsibility); cf. International Ladies' Garment Workers' Union v. NLRB, 237 F.2d 545 (1956) (strikers are not ipso facto agents).

73 E.g., Plumbers \& Pipefitters Local 2, 152 N.L.R.B. 1093, 1106 (1965); NLRB v. Local 50, Bakery \& Confectionery Workers, 339 F.2d 324 (2d Cir. 1964); NLRB v. St. Joe Paper Co., 319 F.2d 819 (2d Cir. 1963); Marine Cooks \& Stewards Union, 92 N.L.R.B. 877 (1950).

74 Steelworkers Local 4373, 133 N.L.R.B. 1508 (1961) (members acted contrary to the rules of the union and the requests of its leaders by refusing to work with other members in bad standing); cf. NLRB v. Teamsters Local 815, 290 F.2d 99 (2d Cir. 1961) (letter following start of walkout not a sufficient disclaimer).

75 See Westwood Plumbers, 122 N.L.R.B. 726, 736 (1958).

76 Flack v. NLRB, 327 F.2d 396 (7th Cir. 1963) (a clear demand that the employer discriminate is unnecessary). Note that "an attempt to cause" does not require that the number of employee members complying be sufficient to produce actual discriminatory employer action. Bylaws have been used as evidence of union purpose. See NLRB v. Operating Eng'rs Local 450, 281 F.2d 313, 315 (5th Gir. 1960); International Typographical Union, 86 N.L.R.B. 951, 962 (1949) (the 8(b)(1)(A) proviso does not preclude bylaws from being admitted as evidence). 
United Brotherhood of Carpenters \& Joiners v. NLRB $B^{77}$ considered the legality of refusals to apply for work with an employer of nonunion men. The Court of Appeals for the District of Columbia Circuit accepted counsel's concession in oral argument that membership compliance in such a case was not an unfair labor practice. ${ }^{78}$ The court did not discuss the coercive effect such refusals might have on an employer who had exhausted the supply of nonunion labor, nor did it give any reason for distinguishing a mass refusal to apply for work from a walkoff by a group of men shortly after accepting a job. When compliance by refusing to apply for work has the same coercive impact as a group walkout, an $8(\mathrm{~b})(2)$ violation would seem to exist.

\section{Maintenance of Closed Shop Bylaws as a Per Se Violation}

In Scofield, Allis-Chalmers and Marine Workers, the Supreme Court considered only the enforcement of bylaws without reaching the question of whether the mere maintenance of a restrictive bylaw constitutes an unfair labor practice. ${ }^{79}$ The Board, however, when dealing with an industry where both employers and employees are union members, ${ }^{80}$ has developed an ill-conceived contractual distinction under which it has approved the maintenance of closed shop bylaws applicable to employee members and condemned the maintenance of such bylaws applicable to employer members.

This distinction was formulated in American Federation of Musicians, $^{81}$ in which the Board summarily ruled that, on the basis of precedent, the maintenance and enforcement of restrictive employee bylaws did not violate the Act, ${ }^{82}$ while ruling that the maintenance of employer member bylaws did violate the Act. In reaching the latter conclusion, the Board characterized employer member bylaws as forbidden closed shop contracts, which violated both $8(b)(1)(A)$ and 8 (b)(2), rather than as membership requirements protected by the proviso to $8(\mathrm{~b})(\mathrm{l})(\mathrm{A}) .{ }^{83}$ Thus, the Board did not even consider whether the proviso protected these bylaws.

\footnotetext{
77286 F.2d 533 (D.C. Cir. 1960).

78 Id. at 538.

79 Mr. Justice White's pronouncement in Scofield that offensive bylaws would be unenforceable stopped short of his suggestion in Allis-Chalmers that some bylaws might be "wholly invalid and unenforceable." 388 U.S. at 198; see note 23 supra.

80 See Glasser v. NLRB, 395 F.2d 401 (2d Cir. 1968) (musicians union).

81165 N.L.R.B. 798 (1967).

82 Id. at 801.

83 Cf. NLRB v. Marine Workers Union, 391 U.S. 418 (1968), on which Scofield relied. See text at note 79 supra. Voluntary compliance with the bylaws in Marine Workers, requiring union members to exhaust internal appellate procedure before filing complaints with the Board, would not violate the Act nor interfere with job rights. Thus, merely declaring those bylaws unenforceable was sufficient to remedy the unfair labor
} 
On appeal, the Second Gircuit, in Glasser v. $N L R B,{ }^{84}$ following the precedents holding that the $8(\mathrm{~b})(\mathrm{l})(\mathrm{A})$ proviso protected employee member bylaws, ${ }^{85}$ affirmed the Board's ruling that maintenance of these bylaws did not violate the Act. The court also affirmed the Board's conclusion that the maintenance and enforcement of employee bylaws did not violate $8(\mathrm{~b})(2)$, although it found the question "somewhat more difficult." "s6 Apparently the operation of the bylaw had not resulted in any readily identifiable acts of employer discrimination, and the court refused to find an $8(\mathrm{~b})(2)$ violation in the "substantial 'chilling effect" "st of such bylaws on the hiring of nonmember musicians by employers who, as union members, were "acutely aware of the bylaw's existence and of the rigorousness of enforcement within the Federation." 88 By developing its "direct approach" test, the court impliedly affirmed Board decisions that the mere existence of closed shop bylaws applicable to employee union members did not violate $8(\mathrm{~b})(2) .{ }^{89}$

The court did not consider the propriety of the Board's holding that the mere existence of employer member bylaws violated the Act, ${ }^{90}$ though that ruling can apparently be reconciled with the direct approach test. Employer member bylaws subject employers to direct

practice. Because employer compliance with closed shop bylaws applicable to them would violate the Act and affect job rights, the Board apparently felt that the more severe remedy of totally invalidating the employer bylaws was justified. Note, however, that there was no danger of conflict with the internal affairs of the union since it had already amended the offensive bylaw. See note 90 infra.

84395 F.2d 401, 406 (2d Cir. 1968), denying review to American Fed'n of Musicians, 165 N.L.R.B. 798 (1967).

$85 \mathrm{Id}$. at 406. See authorities cited note 12 supra.

$80 I d$.

$87 I d$.

$88 I d$.

s9 E.g., Ohio Valley Carpenters' Dist. Council, AFL-CIO, 131 N.L.R.B. 1130 (1961); Bowling Supply and Serv., Inc., 127 N.L.R.B. 1073 (1960). The rationale of these cases, that existence of the bylaws did not constitute an $8(b)(2)$ violation because employers were not bound by union bylaws, was implicitly at issue in the hiring hall cases heard by the Supreme Court in 1961: Teamsters Local 357 v. NLRB, 365 U.S. 667 (1961); NLRB v. News Syndicate Co., 365 U.S. 695 (1961); International Typographical Union v. NLRB, 365 U.S. 705 (1961). A part of the dispute in the hiring hall cases was what evidence was necessary to establish that employers had recognized and agreed to comply with union bylaws. The court did not find the hiring hall arrangements per se unlawful since clever draftsmanship had kept the bylaws from becoming a part of the collective contracts and because it was possible to implement the contracts without dis. criminating against nonmembers. The legality of the bylaws was not considered in those cases although the court indicated that attempts to cause discrimination would violate section $8(b)(2) .365$ U.S. at $673-6$.

90 The union had already amended the offensive bylaw so that it no lezger applied to employers subject to the Board's jurisdiction. 165 N.L.R.B. at 799. 
union discipline, whereas the employee member bylaws exert only indirect pressure on employers.

The Board's contractual distinction between employer and employee closed shop bylaws seems both excessively formal and somewhat unrealistic, particularly in light of the fact that both forms of bylaw express the same closed shop policy. The contractual distinction focuses on the type of sanction prescribed for employers who refuse to adopt that policy. Yet Scofield, by implying that neither bylaw can be enforced by even internal disciplinary proceedings, undercuts whatever rationale existed for placing such great significance on the type of penalty prescribed.

Once the contractual distinction is rejected, the only justification for treating employer bylaws differently than employee bylaws is that employers might be more likely to learn of the existence of employer bylaws than of employee bylaws. This asserted justification is particularly relevant with regard to $8(b)(2)$ violations, for the most persuasive argument for holding that the existence of a closed shop bylaw violates this section is that it puts employers on notice that they must hire either all union men or all nonunion men to avoid labor problems. This argument seems somewhat easier to apply to employer bylaws since the Board certainly can presume that the union expects employers to learn of the policies contained in bylaws expressly applicable to them. However, the argument should be applied also to employee bylaws, ${ }^{91}$ especially in industries where the union can expect widespread employee compliance to inform the employer of its restrictive policy. Acceptance of this theory would call for overruling the Glasser proximity test ${ }^{92}$ and would rebut the presumption that absent an agreement indicating otherwise, employer hiring practices are unilaterally adopted ${ }^{93}$-a presumption which for certain industries was probably unrealistic from the start.

Even when membership compliance is not widespread, the Board

91 To support this argument the Board would have to hold that an employer is charged with knowledge of the bylaws of his employees' unions. The rule making power might be an appropriate means of reaching such a result if it were determined to be desirable. See NLRB v. Wyman-Gordon Co., 394 U.S. 759 (1969). When closed shop conditions do exist, the conditions themselves may evidence the employer's knowledge of the bylaw and his compliance with its policy, and a rule attributing knowledge of union rules to the employer might be unnecessary. Note that in Glasser the court stated that the employers knew of the existence of the bylaw. $395 \mathrm{~F} .2 \mathrm{~d}$ at 406.

92395 F.2d 401, 406 (1968).

93 Ohio Valley Carpenters' Dist. Council, AFL-CIO, 131 N.L.R.B. 1130 (1961); Bowling Supply and Serv., Inc., 127 N.L.R.B. 1073 (1960). See also NLRB v. Brotherhood of Painters, 242 F.2d 477 (10th Cir. 1957) (presumption was applied, though a violation on other grounds was found). 
could use its remedial power to invalidate closed shop employee bylaws under $8(\mathrm{~b})(2)$. Such bylaws are maintained solely to encourage membership compliance. The Board could rule that the union is responsi-. ble under $8(\mathrm{~b})$ for the conduct of any member complying with such a bylaw since he is executing the policy of the union. ${ }^{94}$ The bylaw, as a formal authorization of conduct violating $8(\mathrm{~b})(2),{ }^{95}$ might then be struck down.

Even more persuasive than the above arguments for finding an $8(\mathrm{~b})(2)$ violation is the argument that maintenance violates $8(\mathrm{~b})(\mathrm{l})(\mathrm{A})$. Though any subtle coercion of union members which might flow from existence of an unenforceable bylaw might be too insubstantial to warrant Board intervention, ${ }^{96}$ the coercive effects of the bylaw on nonmembers ${ }^{97}$ seem worthy of judicial recognition. By informing qualified nonmembers that they are unwelcome, the restrictive bylaw may deter nonmembers from applying for work without first seeking to join the union. Further, the bylaw, by formally labeling the nonmember as a cause of strikes and needless friction, ${ }^{98}$ may significantly decrease the employment opportunities of even the most persistent nonmember applicant. By seeking to force an applicant to choose between joining the union and seeking work elsewhere, the union maintaining a closed shop bylaw infringes the section 7 rights of nonmembers. This impairment of nonmember rights is not justified by any legitimate economic goal or by any possibility that the rule could be nondiscriminatorily applied. ${ }^{90}$

94 See Plumbers \& Pipefitters Local 2, 152 N.L.R.B. 1093, 1107 (1965). Cf. United Bhd. of Carpenters \& Joiners v. NLRB, 286 F.2d 533 (D.C. Cir. 1960), which holds that the United Brotherhood was not liable for activities carried out under local closed shop rules it had approved since not all forms of compliance would be illegal. See text at note $\mathbf{7 7}$ supra.

05 See Part II supra.

90 The bylaw's existence might be viewed as a threat to members that they will be penalized if they refuse to engage in conduct contrary to national labor policy. The extent of this threat would seem dependent largely on the degree to which Board orders of unenforceability were publicized within the union.

97 Board orders declaring the bylaws unenforceable would probably not diminish the coercive effects of the bylaws on nonmembers unless the orders were made known to the public at large.

08 Though the Board presumes that there is a certain antagonism and independence of action between employers and unions, see note 93 supra, no such presumption operates between members and nonmembers. While the lack of such a presumption concerning the member-nonmember relationship may be unrealistic, it may be justified by the fact that the union, as exclusive bargaining agent, often represents nonmembers. See text at notes 100-4 infra.

90 These characteristics of the bylaw differentiate it from hiring halls which the Supreme Court has approved. Teamsters Local 357 v. NLRB, 365 U.S. 667 (1961). Hir- 
The duty of fair representation, which Glasser did not consider, appears to be a suitable tool for condemning closed shop bylaws under $8(\mathrm{~b})(\mathrm{l})(\mathrm{A})$. As enunciated by the Board in Miranda Fuel Co. ${ }^{100}$ this doctrine presumes that "Section 7 ... gives employees the right to be free from unfair or irrelevant or invidious treatment by their exclusive bargaining agent in matters affecting their employment"101 and that "section $8(\mathrm{~b})(\mathrm{I})(\mathrm{A})$... prohibits labor organizations, when acting in a statutory representative capacity, from taking action against any employee upon [such] considerations. . . ."102 Union maintenance of a closed shop bylaw seems to discourage otherwise qualified nonmembers from applying for work and to diminish employment opportunities of nonmember applicants, who are "employees" protected by the Act. ${ }^{103}$ Lack of union membership is a characteristic which the Act itself declares an irrelevant criterion of employment. ${ }^{104}$ Thus, by maintaining a closed shop bylaw, an exclusive bargaining agent seems to breach its duty to represent fairly nonmember applicants. It is arguable, of course, that because the union maintains the bylaw unilaterally, rather than by agreement with the employer, it is not acting in a representative capacity. But this argument ignores reality, since the bylaw, by specifying qualifications for employment, is intended to affect employment conditions in the bargaining unit. The only additional element necessary to prove that the closed shop bylaw violates

ing halls serve a legitimate economic purpose, $i d$. at $672-3$, and, at least in theory, can be operated without discrimination. Id. at 676.

100140 N.L.R.B. 181 (1962), enforcement denied, NLRB v. Miranda Fuel Co., 326 F.2d 172 (2d Cir. 1963). The Supreme Court has never ruled on whether the $\$ 9(a)$ duty of fair representation can be read into $\S 8(\mathrm{~b})(1)(\mathrm{A})$. See Vaca v. Sipes, 386 U.S. 171 (1967). (The Court discussed the implication of Board adoption of the fair representation duty on the doctrine of exclusive jurisdiction, though the discussion was based only on the assumption that the duty could be read into $8(\mathrm{~b})(1)(\mathrm{A})$.) The Fifth Circuit and the District of Columbia Circuit have approved the Board's adoption of the representation duty in unfair labor practice proceedings. United Rubber Workers Local 12 v. NLRB, 368 F.2d 12 (5th Cir. 1966); Truck Drivers Local 568 v. NLRB, 379 F.2d 137 (D.C. Cir. 1967). The reasoning in the Truck Drivers opinion seems questionable since it inferred that the Supreme Court in Vaca $v$. Sipes approved reading the fair representation duty into $8(\mathrm{~b})(1)(\mathrm{A})$. Id. at 141. An inference of Supreme Court approval of the Board's Miranda Fuel Co. doctrine can, however, be found in Scofield v. NLRB, 394 U.S. 423 (1969). Whether a union breached its duty of fair representation by enforcing a rule was considered as relevant to whether the rule was enforceable under 8(b)(I)(A). Id. at 436. See Note, Fair Representation and Union Discipline, 79 YALE L.J. 730, 744 (1970).

101 Miranda Fuel Co., 140 N.L.R.B. 181, 185 (1962).

102 Id.

103 Phelps Dodge Corp. v. NLRB, 313 U.S. 177, 183 (1941).

10429 U.S.C. $\$ \S 157,158(\mathrm{a})(3), 158(\mathrm{~b})(2)$ (1964). See Radio Officers' Union v. NLRB, 347 U.S. 17, 40 (1954). 
the Act is that the bylaw under attack is maintained by a union which acts as an exclusive bargaining agent, under a duty to members and nonmembers alike. But since a closed shop bylaw would clearly be a dead letter if the union maintaining it was not, in any instance, a majority representative, there should be no objection on this ground to the adoption of a per se rule condemning such bylaws under $8(\mathrm{~b})(\mathrm{I})(\mathrm{A})$.

Considerations of policy and administrative convenience support the doctrinal analyses urged above. Prohibiting the maintenance of closed shop bylaws would eliminate many of the troublesome questions of causation and union intent in deciding in each individual case whether specific efforts to implement the bylaw violate the Act. The Board could then consider whether other union bylaws or statements of union policy, such as motions adopted at conventions, should be subject to the per se rule. ${ }^{105}$ On balance, a per se rule would extend the protection of the Act without increasing, and possibly lessening, the Board's burgeoning case load.

A possible objection to adoption of a per se rule is that invalidating the bylaws might not affect the employment opportunities of nonmembers, but only encourage unions to use more informal but equally effective methods of implementing closed shop policies. ${ }^{108}$ The most glaring weakness of this objection is that it assumes that more informal methods are equally effective, an assumption which can be factually corroborated only after the adoption of a per se rule. Moreover, this objection seems equally applicable to any interference with internal union affairs. The Board has regulated internal union affairs when employment opportunities have been affected by racially motivated rules $^{107}$ and by rules applicable to employer members. ${ }^{108}$ It should also do so when rules such as closed shop bylaws, which serve no legitimate interest of members, affect basic statutory rights of nonmembers who are entitled to fair representation. ${ }^{109}$ Reluctance to interfere with

105 For example, a union having a bylaw requiring members to be loyal might adopt a motion at a convention stating that loyal members must not work with nonmembers.

106 Newspaper articles and word of mouth could be used to encourage compliance with leadership desires for a closed shop. These might be protected forms of communication. See 29 U.S.C. \$ 158(c) (1964):

The expressing of any views, argument, or opinion, or the dissemination thereof, whether in written, printed, graphic, or visual form, shall not constitute or be evidence of an unfair labor practice under any of the provisions of this subchapter, if such expression contains no threat of reprisal or force or promise of benefit.

107 Houston Maritime Ass'n, 168 N.L.R.B. No. 83, 66 L.R.R.M. 1337 (1967) (a racially motivated freeze was invalidated).

108 American Fed'n of Musicians, 165 N.L.R.B. 798 (1967). See text at note 90 supra. 109 There is some authority for holding that a traditional $8(\mathrm{~b})(2)$ violation also 
internal union affairs is not an excuse for allowing unions to use their constitutions to legitimatize efforts to implement discriminatory practices that are repugnant to the basic values of the NLRA.

breaches the $8(\mathrm{~b})(\mathrm{I})(\mathrm{A})$ duty of fair representation. Carpenters Local 143, 170 N.L.R.B. No. 97, 67 L.R.R.M. 1489 (1968). (The trial examiner found a breach of the 8(b)(l)(A) duty in an 8(b)(2) violation, though the Board disposed of the case under 8(b)(2) only.) Cf. Miami Valley Carpenters' Dist. Council, 129 N.L.R.B. 517 (I960) (threat of bodily harm necessary for conduct violating $8(\mathrm{~b})(2)$ to also violate $8(\mathrm{~b})(1)(\mathrm{A}))$. 